\title{
Profil Bibir dan Posisi Insisivus Perawatan Kasus Borderline Klas I dengan Pencabutan dan Tanpa Pencabutan
}

\author{
Yenni Hanimastuti*, Pinandi Sri Pudyani**, dan Darmawan Sutantyo** \\ *Program Studi Ortodonsia PPDGS Fakultas Kedokteran Gigi Universitas Gadjah Mada \\ **Bagian Ortodonsia Fakultas Kedokteran Gigi Universitas Gadjah Mada \\ **Jl Denta no 1 Sekip Utara Yogyakarta, e-mail: yennihanimastuti@gmail.com
}

\begin{abstract}
ABSTRAK
Penentuan rencana perawatan ortodontik dengan pencabutan atau tanpa pencabutan masih menjadi perdebatan, terutama pada kasus borderline.Perawatan ortodontik dengan atau tanpa pencabutan dapat mempengaruhi profil wajah.Perubahan pada penampilan wajah terjadi akibat adanya perubahan posisi gigi anterior yang dapat mempengaruhi perubahan profil jaringan lunak wajah terutama pada daerah bibir.Penelitian ini bertujuan mengetahui perbandingan perubahan profil bibir dan posisi gigi insisivus pada kasus borderline klas I antara perawatan dengan pencabutan 4 premolar kedua dan tanpa pencabutan. Penelitian dilakukan pada 28 sefalogram lateral kasus borderline klas I yang dirawat dengan teknik straight wire, terdiri dari 2 kelompok (13 kasus dengan pencabutan dan 15 kasus tanpa pencabutan).Masing-masing sefalogram dilakukan pengukuran profil bibir,yaitu jarak bibir atas dan bawah terhadapVertical Reference Plane (VRP) dan sudut interlabial; serta posisi gigi insisivus, yaitu jarak gigi insisivus atas dan bawah terhadap Vertical Reference Plane (VRP), sebelum dan sesudah perawatan. Hasil penelitian menunjukkan pada tahap awal perawatan kedua kelompok memiliki karakteristik profil bibir dan posisi gigi insisivus yang sama $(p>0,05)$. Terdapat perbedaan bermakna $(p<0,05)$ pada perubahan posisi bibir, sudut interlabial, dan posisi gigi insisivus antara kelompok yang dirawat dengan pencabutan dan tanpa pencabutan setelah perawatan ortodontik. Kesimpulan penelitian ini adalah profil bibir dan posisi gigi insisivus pada kasus borderline klas I yang dirawat dengan pencabutan 4 premolar kedua menjadi lebih retrusif daripada profil bibir dan posisi gigi insisivus kasus borderline klas I yang dirawat tanpa pencabutan.
\end{abstract}

Maj Ked Gi; Desember 2013; 20(2): 132-139.

Kata kunci: profil bibir, posisi insisivus, borderline klas I, pencabutan premolar kedua, tanpa pencabutan.

\begin{abstract}
Lips Profile And Incisivus Position In Class Iborder Line Cases With Or Wthout Extraction. Determining whether an orthodontic treatment plan should be with or without extraction is still debatable, particularly for borderline cases. In fact, such a treatment could affect the facial profile. The change in facial appearance is caused by the reposition of anterior teeth which could cause facial soft tissue profile changes, particularly at the lips area. The aim of this study is to compare the changes of lips profile and incisors position in class I borderline cases which have been treated with extraction of 4 second premolars and non-extraction. The study was conducted on 28 lateral cephalograms of class I borderline cases which have been treated with straight wire technique, as divided into two groups (13 extraction and 15 non-extraction cases). Each cephalograms had measured on lips profile, which was the distance of upper and lower lips to Vertical Reference Plane (VRP) and interlabial angle; and the position of incisors, which was the distance of upper and lower incisors to Vertical Reference Plane (VRP), at pre and post-treatment. The results of this study have shown that at the initial treatment, lips profile and incisors position for both groups have similar characteristics $(p>0,05)$. There are significant differences $(p<0.05)$ on lips position, interlabial angle, and incisors position changes between the extraction and nonextractiion cases after orthodontic treatment. From this study, it can be concluded that lips profile and incisors position in class I borderline cases treated with the extraction of second bicuspid are more retruded than that of non-extraction cases.

Maj Ked Gi; Desember 2013; 20(2): 132-139.
\end{abstract}

Keywords: lips profile, incisivus position, class I borderline cases, extraction, non-extraction, second bicuspid

\section{PENDAHULUAN}

Tujuan perawatan ortodontik adalah untuk mendapatkan oklusi gigi yang optimal dengan adaptasi fisiologik dan fungsi normal, perbaikan dentofasial dengan estetis yang baik dan kestabilan hasil perawatan.' Jaringan lunak wajah merupakan faktor penting yang berperan membentuk estetika wajah, fungsi bicara, dan fungsi lainnya. Profil 
jaringan lunak wajah yang harmonis merupakan tujuan penting perawatan ortodontik, namun terkadang hal ini sulit dicapai, sebagian disebabkan oleh tingginya variasi ketebalan bibir serta adanya respon adaptasi jaringan yang berbeda pada tiap individu. ${ }^{2.3}$ Perubahan pada penampilan wajah terjadi akibat adanya perubahan posisi gigi anterior yang dapat mempengaruhi perubahan profil jaringan lunak wajah terutama pada daerah bibir, sehingga penelitian mengenai perubahan posisi bibir dan gigi menjadi sangat penting untuk mempertimbangkan kebutuhan pasien akan perubahan penampilan estetika wajah. ${ }^{4}$

Penilaian kritis terhadap kasus ortodontik dibutuhkan untuk mendapatkan diagnosis dan rencana perawatan yang tepat bagi pasien, sebab terdapat variasi yang luas dalam perawatan ortodontik untuk tiap-tiap individu yang berbeda. ${ }^{3,5}$ Perawatan ortodontik tanpa pencabutan menimbulkan asumsi bahwa penyusunan gigi geligi dapat menyebabkan protraksi gigi anterior dan profil wajah, sementara pada perawatan ortodontik dengan pencabutan dapat menyebabkan retroklinasi gigi-gigi anterior dan meretraksi profil wajah sebab penyusunan gigi geligi akan menempati ruang bekas pencabutan. ${ }^{6}$

Studi komparatif terhadap profil wajah dan hasil penelitiannya dapat menjadi bahan pertimbangan dalam menyusun rencana perawatan ortodontik yang tepat. Beberapa prosedur ortodontik, termasuk pencabutan gigi, dapat mempengaruhi profil jaringan lunak tetapi konsekuensi dari pencabutan masih menjadi kontroversi. ${ }^{7.8}$ Beberapa penelitian menyatakan bahwa perawatan ortodontik dengan pencabutan premolar dapat menyebabkan bibir atas dan bibir bawah menjadi lebih retrusif sebagai respon dari retroklinasi gigi insisivus, ${ }^{7,910}$ tetapi penelitian lainnya menyatakan bahwa perawatan ortodontik dengan pencabutan premolar tidak merubah profil wajah. ${ }^{11}$

Kontroversi perawatan ortodontik dengan pencabutan dan tanpa pencabutan menjadi semakin meningkat jika dihubungkan dengan kasus borderline. ${ }^{8}$ Konsep pasien borderline telah didiskusikan secara luas dalam ortodontik. Carey ${ }^{12}$ merupakan orang pertama yang menggunakan istilah borderline dalam literature. Carey menyarankan pasien dengan diskrepansi panjang lengkung kurang dari 2,5 $\mathrm{mm}$ harus dirawat dengan tanpa pencabutan; pasien dengan diskrepansi panjang lengkung lebih dari $5 \mathrm{~mm}$ harus dirawat dengan pencabutan 4 premolar pertama; pasien intermediet atau borderline dengan diskrepansi panjang lengkung 2,5 - $5 \mathrm{~mm}$ dirawat dengan pencabutan 4 premolar kedua. ${ }^{12,13}$ Howes $^{14}$ menyatakan bahwa keberjejalan gigi lebih sering terjadi karena defisiensi lebar lengkung dibandingkan defisiensi panjang lengkung. Howes ${ }^{14}$ menemukan hubungan antara total lebar mesiodistal gigi-gigi dari anterior hingga molar kedua dengan lebar lengkung gigi pada regio premolar pertama, sehingga didapatkan rumusan sebagai berikut: 1) indeks fossa canina $<37 \%$ merupakan indikasi perawatan dengan pencabutan, 2) indeks fossa canina $>44 \%$ kemungkinan perawatan dapat dilakukan tanpa pencabutan gigi-gigi, 3) indeks fossa canina 37\%-44\% merupakan kasus borderline, perawatan dapat dilakukan dengan pencabutan atau tanpa pencabutan.

Malrelasi transversal ataupun vertikal pada rahang, seperti gigi yang berjejal merupakan penyebab umum dari maloklusi klas I dan umumnya perawatan dapat dilakukan dengan pencabutan atau tanpa pencabutan gigi-gigi permanen. ${ }^{15}$ Penelitian mengenai pengaruh perawatan ortodontik terhadap profil wajah umumnya fokus pada aspek prediksi hubungan antara gigi insisivus dan bibir, tujuannya adalah untuk melihat perubahan posisi gigi insisivus terhadap perubahan profil bibir. $^{10}$ Penelitian $\mathrm{Xu}$ dkk. ${ }^{13}$ membandingkan hasil perawatan kasus borderline yang dirawat dengan pencabutan dan tanpa pencabutan pada pasien China serta penelitian Lim dkk. ${ }^{7}$ pada pasien borderline Korea. Hasil penelitian menyatakan perbedaan hasil perawatan yang signifikan antara pencabutan dan tanpa pencabutan terdapat pada profil wajah, yaitu berkurangnya protrusif bibir pada perawatan dengan pencabutan, sehingga terjadi peningkatan profil wajah yang lebih baik sesudah perawatan 
dengan pencabutan. Konstantonis ${ }^{16}$ menyatakan bahwa pada perawatan kasus borderline klas I yang dirawat dengan pencabutan menghasilkan bibir atas dan bawah menjadi lebih retraksi, sementara pada kelompok tanpa pencabutan menghasilkan retraksi bibir atas dan protraksi bibir bawah yang signifikan. Penelitian Germec dan Taner ${ }^{8}$ pada kasus borderline maloklusi klas I menyatakan bahwa pada kelompok dengan pencabutan terjadi retraksi ringan gigi insisivus namun tidak merubah posisi bibir, sedangkan pada kelompok tanpa pencabutan, posisi gigi insisivus maksila tetap, namun gigi insisivus mandibula serta bibir atas dan bawah sedikit protraksi. Perubahan profil yang terjadi pada kedua kelompok masih berada dalam batas normal, sehingga hasil akhir perawatan kedua kelompok menunjukkan keseimbangan estetika wajah.

Perubahan profil jaringan lunak akibat perawatan ortodontik diharapkan dapat menghasilkan profil yang lebih baik pada akhir perawatan, namun tidak menutup kemungkinan hasil perawatan yang diperoleh adalah sebaliknya, sehingga untuk menganalisis hasil perawatan dapat dilakukan dengan membandingkan ukuran-ukuran sebelum dan sesudah perawatan. ${ }^{17}$ Perubahan profil bibir dan posisi gigi dapat diketahui dengan pengukuran sefalogram lateral sebelum dan setelah perawatan. Pengukuran sefalogram dapat dilakukan melalui pengukuran linier dan anguler. ${ }^{18}$ Al-Abdwani ${ }^{19}$ menggunakan referensi Horizontal Reference Plane (HRP) dan Vertikal Reference Plane (VRP) untuk mengukur perubahan posisi bibir dan gigi secara linier sebelum dan setelah perawatan. Horizontal Reference Plane (HRP) adalah bidang horizontal yang dibentuk oleh sudut $7^{\circ}$ ke arah inferior dari bidang Sella-Nasion (SN) yang melalui titik Sella (S). Vertikal Reference Plane (VRP) adalah bidang vertikal yang dibentuk tegak lurus dari titik Sella (S) terhadap Horizontal Reference Plane (HRP) ke arah inferior. Al-labban ${ }^{2}$ dalam penelitiannya menggunakan sudut interlabial untuk mengevaluasi dan menganalisis perubahan profil bibir atas dan bibir bawah. Sudut interlabial adalah sudut yang dibentuk dari perpotongan dua garis, yaitu dari titik posterior columella $(\mathrm{PCm})$ ke titik labrale superior (Ls) serta dari titik pogonion jaringan lunak (Pog') ke labrale inferior (Li).

Penelitian ini bertujuan untuk mengetahui perbandingan perubahan profil bibir dan posisi gigi insisivus pada kasus borderline klas I antara perawatan ortodontik dengan pencabutan premolar kedua dan tanpa pencabutan premolar.

\section{METODE PENELITIAN}

Subjek penelitian didapat dari data laporan pasien yang telah selesai dirawat ortodontik oleh karyasiswa Program Pendidikan Dokter Gigi Spesialis Program Studi Ortodonsia Fakultas Kedokteran Gigi Universitas Gadjah Mada Yogyakarta tahun 2000 - 2012 dengan kriteria sebagai berikut: 1) kasus borderline maloklusi klas I yang dirawat dengan teknik straight wire; 2) usia antara 18-35 tahun; 3) overjet $2-4 \mathrm{~mm}$; 4) dilakukan pencabutan 4 premolar kedua atau perawatan tanpa pencabutan. Kasus borderline klas I adalah yang memiliki diskrepansi panjang lengkung 2,5 - $5 \mathrm{~mm}$ dan indeks fossa canina antara $37 \%-44 \%$, diukur dari studi model. Objek penelitian adalah sefalogram lateral sebelum dan sesudah perawatan ortodontik dari pasien yang telah memenuhi kriteria pemilihan subjek penelitian. Sefalogram lateral dari masingmasing subjek penelitian diseleksi kelengkapan sebelum dan setelah perawatan ortodontik dan kejelasan bidang dan titik-titik referensi. Didapatkan 28 data laporan pasien yang memenuhi kriteria, terdiri dari 15 kasus borderline klas I yang dirawat tanpa pencabutan dan 13 kasus borderline klas I Angle yang dirawat dengan pencabutan premolar kedua.

Dilakukan panapakan pada sefalogram sebelum dan setelah perawatan ortodontik dengan menggunakan kertas asetat dengan pensil $4 \mathrm{H}$ di atas illuminator.Bidang dan titik-titik yang digunakan dapat dilihat pada Tabel 1 dan Gambar 1. 
Tabel 1.SefalometriLandmarks jaringan keras dan jaringan lunak

\begin{tabular}{|c|c|}
\hline Sefalometri Landmarks & Definisi \\
\hline Upper Incisal Edge (UIE) & titik paling prominen/menonjol pada ujung incisal insisivus atas. \\
\hline Lower Incisal Edge (LIE) & titik paling prominen/menonjol pada ujung incisal insisivus bawah. \\
\hline Labrale superior (Ls) & $\begin{array}{l}\text { titik yang mengindikasikan batas mucocutaneus bibir atas, titik terdepan } \\
\text { pada kurva bibir atas. }\end{array}$ \\
\hline Labrale inferior (Li) & $\begin{array}{l}\text { titik yang mengindikasikan batas mucocutaneus bibir bawah, titik } \\
\text { terdepan pada kurva bibir bawah. }\end{array}$ \\
\hline Posterior Columella (PCm) & titik tercekung diantara bibir atas dan batas bawah hidung \\
\hline Pogonion jaringan lunak (Pog') & titik terdepan dari jaringan lunak dagu dalam bidang midsagital \\
\hline $\begin{array}{l}\text { Horizontal Reference Plane } \\
\text { (HRP) }\end{array}$ & $\begin{array}{l}\text { sebuah bidang horizontal yang dibentuk oleh sudut sebesar } 7^{\circ} \text { ke arah } \\
\text { inferior dari bidang Sella-Nasion ( } S N \text { ) yang melalui titik Sella (S). }\end{array}$ \\
\hline Vertikal Reference Plane (VRP) & $\begin{array}{l}\text { sebuah bidang vertikal yang dibentuk tegak lurus dari titik Sella (S) } \\
\text { terhadap Horizontal Reference Plane (HRP) ke arah inferior }\end{array}$ \\
\hline Sudut interlabial (iLa) & $\begin{array}{l}\text { sudut yang dibentuk dari perpotongan dua garis, yaitu dari titik posterior } \\
\text { columella (PCm) ke titik labrale superior (Ls) serta dari titik pogonion } \\
\text { jaringan lunak (Pog') ke labrale inferior ( } \mathrm{Li})\end{array}$ \\
\hline
\end{tabular}

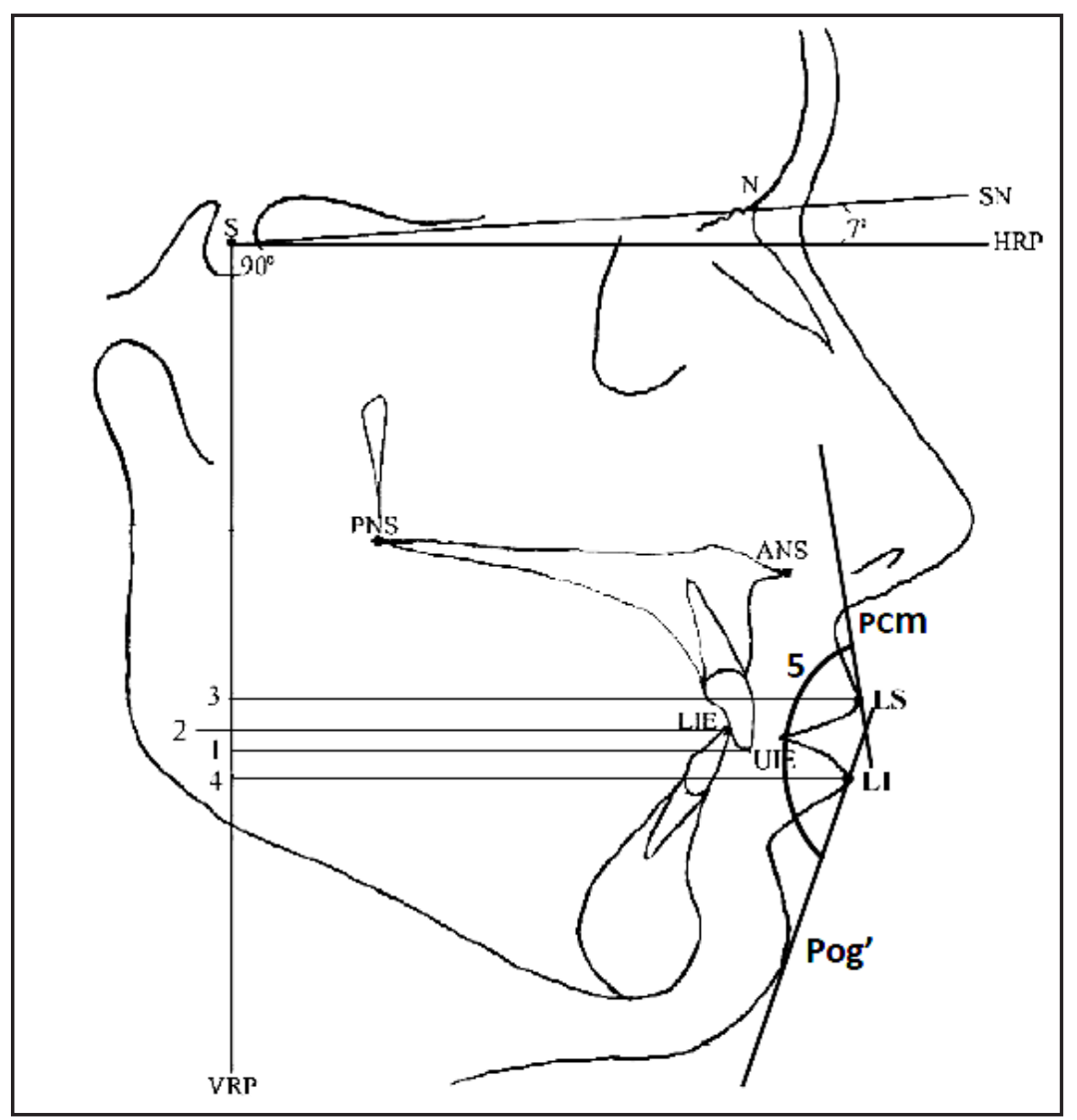

Gambar 1. Sefalometri landmarks untuk pengukuran linier bibir dan gigi insisivus; 1) jarak horizontal insisivus atas, 2) jarak horizontal insisivus bawah, 3) jarak horizontal bibir atas, 4) jarak horizontal bibir bawah, 5) sudut interlabial 2,19 
Tabel 2. Rerata dan simpangan baku profil bibir dan posisi gigi insisivus

\begin{tabular}{lllcll}
\hline \multicolumn{1}{c}{ Variabel } & \multicolumn{1}{c}{ Perawatan } & N & $\begin{array}{c}\text { Sebelum } \\
\text { perawatan }\end{array}$ & $\begin{array}{c}\text { Sesudah } \\
\text { perawatan }\end{array}$ & Perubahan \\
\hline LS - VRP $(\mathrm{mm})$ & Pencabutan & 13 & $87,83 \pm 6,27$ & $86,12 \pm 6,92$ & $-1,70 \pm 1,85$ \\
& Tanpa Pencabutan & 15 & $87,77 \pm 7,45$ & $88,52 \pm 7,36$ & $0,74 \pm 1,26$ \\
LI - VRP $(\mathrm{mm})$ & Pencabutan & 13 & $85,30 \pm 7,13$ & $82,24 \pm 7,57$ & $-3,05 \pm 2,84$ \\
& Tanpa Pencabutan & 15 & $85,50 \pm 9,74$ & $85,59 \pm 9,29$ & $0,08 \pm 1,69$ \\
Sudut Interlabial & Pencabutan & 13 & $138,84 \pm 9,98$ & $143,88 \pm 9,90$ & $4,96 \pm 2,75$ \\
(derajat) & Tanpa Pencabutan & 15 & $142,96 \pm 7,29$ & $141,76 \pm 8,12$ & $-1,2 \pm 3,57$ \\
UIE - VRP $(\mathrm{mm})$ & Pencabutan & 13 & $75,78 \pm 6,17$ & $71,45 \pm 7,03$ & $-4,25 \pm 3,58$ \\
& Tanpa Pencabutan & 15 & $76,88 \pm 5,48$ & $76,78 \pm 5,68$ & $0,09 \pm 1,41$ \\
LIE - VRP $(\mathrm{mm})$ & Pencabutan & 13 & $72,71 \pm 6,01$ & $68,65 \pm 6,81$ & $-4,06 \pm 2,87$ \\
& Tanpa Pencabutan & 15 & $73,90 \pm 4,89$ & $73,96 \pm 5,65$ & $0,05 \pm 1,52$ \\
\hline
\end{tabular}

Ket:

VRP : Vertical Reference Plane

UIE : Upper Incisal Edge (ujung insisal Insisivus atas)

LS : Labrale Superior (bibir atas)

LIE : Lower Incisal Edge (ujung insisal Insisivus bawah)

$\mathrm{LI} \quad$ : Labrale Inferior (bibir bawah)

Subjek penelitian dibagi dalam dua kelompok, yaitu 1) kelompok 1: kelompok dengan pencabutan; 2) kelompok 2: kelompok tanpa pencabutan. Dilakukan pengukuran profil bibir, yaitu jarak bibir atas dan bibir bawah terhadap Vertical Reference Plane (VRP) dan sudut interlabial, serta posisi gigi insisivus, yaitu jarak gigi insisivus atas dan insisivus bawah terhadap Vertical Reference Plane (VRP) pada kedua kelompok sebelum dan sesudah perawatan, menggunakan jangka sorong dan protraktor sefalometri pada masing-masing sefalogram (Gambar 1). Sefalometri landmarks dapat di lihat dalam tabel 1.

Pengukuran dilakukan dua kali oleh peneliti dengan selang waktu satu minggu. Hasil dari kedua pengukuran dibandingkan, jika nilainya sama atau kurang dari $0,5 \mathrm{~mm}(\leq 0,5 \mathrm{~mm})$ untuk pengukuran linier dan sama atau kurang dari $1^{\circ}\left(\leq 1^{\circ}\right)$ untuk pengukuran angular, maka dihitung reratanya. Penapakan dan pengukuran ketiga dilakukan bila perbedaan hasil kedua pengukuran linier lebih besar dari $0,5 \mathrm{~mm}(>0,5 \mathrm{~mm})$ dan pengukuran anguler lebih dari $1^{\circ}\left(>1^{\circ}\right)$. Hasilnya dibandingkan dengan kedua nilai sebelumnya, kemudian nilai rerata ditentukan dari dua nilai yang terdekat. ${ }^{20}$ Data hasil pengukuran dianalisis menggunakan independent $t$ test untuk mengetahui perbandingan perubahan posisi bibir, posisi gigi, dan sudut interlabial diantara kedua kelompok.

\section{HASIL PENELITIAN}

Data hasil pengukuran profil bibir dan posisi gigiinsisivus sebelum dan sesudah perawatan padakelompok dengan pencabutan dan tanpa pencabutandapat dilihat pada Tabel 2 .

Pada kelompok yang dirawat dengan pencabutan, rerata perubahan jarak bibir atas (LS) terhadap Vertical Reference Plane (VRP) setelah perawatan adalah $-1,70 \mathrm{~mm} \pm 1,85 \mathrm{~mm}$, sementara pada kelompok tanpa pencabutan rerata perubahan posisi bibir atas (LS) terhadap Vertical Reference Plane (VRP) adalah 0,74 $\mathrm{mm} \pm 1,26 \mathrm{~mm}$ (Tabel 2). 
Nilai negatif menunjukkan terjadi pengurangan jarak posisi bibir terhadap Vertical Reference Plane (VRP) sesudah perawatan ortodontik. Rerata perubahan sudut interlabial pada kelompok dengan pencabutan $4,96^{\circ} \pm 2,75^{\circ}$, sementara pada kelompok tanpa pencabutan rerata perubahan sudut interlabial $-1,2^{\circ} \pm 3,57^{\circ}$ (Tabel 2). Hasil tersebut menunjukkan pada kelompok yang dirawat dengan pencabutan 4 premolar kedua profil bibir dan posisi gigi insisivus berubah kearah posterior atau terjadi retraksi bibir dan gigi insisivus setelah perawatan ortodontik.
Yenni H., dkk.: Profil Bibir dan Posisi Insisivus ...

Dilakukan analisis perbandingan pada kedua kelompok sebelum dilakukan per-awatan ortodontik menggunakan inde-pendent t-test, dapat dilihat pada Tabel 3. Hasil analisis menunjukkan karakteristik profil bibir dan posisi gigi insisivus kedua kelompok sebelum dilakukan perwatan ortodontik adalah tidak berbeda $(p>0,05)$. Tabel 4 menunjukkan perbandingan peru-bahan profil bibir dan posisi gigi insisivus antara kelompok dengan pencabutan dan tanpa pencabutan.

Tabel 3. Perbandingan profil bibir dan posisi gigi insisivus sebelum perawatan ortodontik

\begin{tabular}{|c|c|c|c|c|}
\hline Variabel & & $\mathrm{N}$ & $\mathrm{t}$ & Sig \\
\hline \multirow[t]{2}{*}{$\mathrm{LS}-\mathrm{VRP}(\mathrm{mm})$} & Pencabutan & 13 & \multirow{2}{*}{0,22} & \multirow{2}{*}{0,982} \\
\hline & Tanpa Pencabutan & 15 & & \\
\hline \multirow[t]{2}{*}{ LI - VRP (mm) } & Pencabutan & 13 & \multirow{2}{*}{$-0,61$} & \multirow{2}{*}{0,952} \\
\hline & Tanpa Pencabutan & 15 & & \\
\hline \multirow[t]{2}{*}{ Sudut Interlabial (derajat) } & Pencabutan & 13 & \multirow{2}{*}{$-1,258$} & \multirow{2}{*}{0,219} \\
\hline & Tanpa Pencabutan & 15 & & \\
\hline \multirow[t]{2}{*}{ UIE - VRP (mm) } & Pencabutan & 13 & \multirow{2}{*}{$-0,5$} & \multirow{2}{*}{0,621} \\
\hline & Tanpa Pencabutan & 15 & & \\
\hline \multirow[t]{2}{*}{ LIE - VRP (mm) } & Pencabutan & 13 & \multirow{2}{*}{$-0,577$} & \multirow{2}{*}{0,569} \\
\hline & Tanpa Pencabutan & 15 & & \\
\hline
\end{tabular}

Ket: tingkat kemaknaan $p<0,05$

Tabel 4. Hasil analisis independent $t$ test perubahan profil bibir dan posisi gigi insisivus

\begin{tabular}{|c|c|c|c|c|}
\hline Variabel & & $\mathrm{N}$ & $t$ & Sig \\
\hline \multirow[t]{2}{*}{$\mathrm{LS}-\mathrm{VRP}(\mathrm{mm})$} & Pencabutan & 13 & \multirow[b]{2}{*}{$-4,144$} & \multirow[b]{2}{*}{$0,000 *$} \\
\hline & Tanpa Pencabutan & 15 & & \\
\hline \multirow[t]{2}{*}{$\mathrm{LI}-\mathrm{VRP}(\mathrm{mm})$} & Pencabutan & 13 & \multirow[b]{2}{*}{$-3,612$} & \multirow[b]{2}{*}{$0,001 *$} \\
\hline & Tanpa Pencabutan & 15 & & \\
\hline \multirow[t]{2}{*}{ Sudut Interlabial (derajat) } & Pencabutan & 13 & \multirow{2}{*}{5,045} & \multirow{2}{*}{$0,000 *$} \\
\hline & Tanpa Pencabutan & 15 & & \\
\hline \multirow[t]{2}{*}{ UIE - VRP (mm) } & Pencabutan & 13 & \multirow{2}{*}{$-4,147$} & \multirow{2}{*}{$0,000 *$} \\
\hline & Tanpa Pencabutan & 15 & & \\
\hline \multirow[t]{2}{*}{ LIE - VRP (mm) } & Pencabutan & 13 & \multirow{2}{*}{$-4,826$} & \multirow{2}{*}{$0,000 *$} \\
\hline & Tanpa Pencabutan & 15 & & \\
\hline
\end{tabular}

Ket: *p<0,05 
Hasil analisis independentttest menunjukkan terdapat perbedaan yang signifikan pada perubahan posisi bibir atas dan bawah, perubahan sudut interlabial, serta perubahan posisi gigi insisivus atas dan bawah antara kelompok dengan pencabutan dan tanpa pencabutan sesudah perawatan ortodontik (Tabel 4).

\section{PEMBAHASAN}

Hasil penelitian menunjukkan bahwa profil bibir dan posisi gigi insisivus pada kasus borderline klas I yang dirawat dengan pencabutan 4 premolar kedua menjadi lebih retrusif daripada profil bibir dan posisi gigi insisivus perawatan tanpa pencabutan. Hal tersebut kemungkinan terjadi karena adanya gaya resiprokal dari gigi-gigi anterior dan gigigigi posterior pada saat penutupan ruang bekas pencabutan, sehingga terjadi retraksi pada gigi-gigi anterior. Retraksi bibir atas dan bawah terjadi karena adanya pengaruh respon bibir terhadap retraksi gigi-gigi anterior. ${ }^{10}$ Brock dkk. ${ }^{21}$ menyatakan bahwa perubahan inklinasi dan posisi gigi geligi dapat terjadi karena adanya protraksi ataupun retraksi gigi, hal ini secara langsung akan mempengaruhi jaringan lunak sekitarnya, terutama profil bibir.

Pada penelitian ini, perawatan dengan pencabutan menunjukkan adanya retraksi gigi inisisivus dan bibir namun retraksi yang terjadi pada gigi inisisivus lebih besar daripada retraksi pada bibir.Hal tersebut kemungkinan disebabkan ketebalan jaringan lunak yang melapisi gigi geligi dan tulang sangat bervariasi, serta bibir merupakan struktur yang sangat fleksibel terdiri dari otototot yang dilapisi oleh lapisan kulit pada bagian luar serta membran mukosa dan submukosa pada bagian dalamnya.Beberapa otot ekspresi melekat pada otot-otot bibir. ${ }^{2}$ Kasai $^{22}$ mengatakan hubungan antara struktur jaringan keras dan profil jaringan lunak sangat bervariasi. Hal tersebut disebabkan beberapa bagian struktur jaringan keras dan jaringan lunak sangat melekat erat namun beberapa bagian lainnya bebas atau tidak melekat satu sama lain, selain itu karakteristik jaringan lunak dipengaruhi oleh panjangnya, ketebalan, dan aspek fungsional seperti ketegangan jaringan.
Para klinisi harus menyadari bahwa perawatan ortodontik dapat mempengaruhi perubahan profil wajah yang terutama dipengaruhi oleh perubahan gigi-gigi anterior. Lim dkk. ${ }^{7}$ menyatakan terdapat banyak faktor yang menentukan perlu atau tidaknya dilakukan pencabutan, diantaranya adalah diskrepansi panjang lengkung, protrusi insisivus, curve of Spee, pola pertumbuhan dentofasial, estetika fasial, usia pasien, dan keluhan utama pasien. Profil fasial kemungkinan juga berkontribusi dalam menentukan keputusan perawatan untuk dilakukan pencabutan atau tanpa pencabutan, terutama pada kasus borderline.

Analisis Carey ${ }^{12}$ pada kasus borderline dengan diskrepansi panjang lengkung antara $2,5 \mathrm{~mm}-5 \mathrm{~mm}$ perawatan dapat dilakukan dengan pencabutan ataupun tanpa pencabutan dan bila dilakukan pencabutan maka lebih dipilih untuk mencabut gigi premolar kedua. Keputusan untuk melakukan pencabutan atau tanpa pencabutan ini dibuat berdasarkan posisi gigi molar ketiga, fleksibilitas jaringan labial, dan tipe wajah individual. Kontrol anchorage merupakan hal yang sangat penting agar saat penutupan ruang bekas pencabutan dapat mengendalikan besarnya retraksi anterior dan protraksi gigi molar-premolar. Umumnya pada kasus borderline klas I pasien dengan keseimbangan wajah yang baik, penutupan ruang bekas pencabutan digunakan minimum anchorage untuk mengurangi besarnya retraksi gigi anterior, sehingga akan didapatkan hasil perawatan dengan

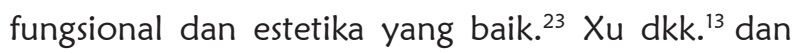
Lim dkk. ${ }^{7}$ menyatakan bahwa pada kasus borderline, perbedaan hasil perawatan yang signifikan antara pencabutan dan tanpa pencabutan terdapat pada perubahan profil wajah, yaitu terjadi penurunan protrusi bibir pada perawatan dengan pencabutan, sehingga terjadi peningkatan profil wajah yang lebih baik sesudah perawatan dengan pencabutan.

\section{KESIMPULAN}

Berdasarkan penelitian yang telah dilakukan, maka dapat disimpulkan bahwa profil bibir pada kasus borderline klas I yang dirawat dengan pencabutan 4 premolar kedua menjadi lebih 
retrusif daripada profil bibir kasus borderline klas I yang dirawat tanpa pencabutan.Posisi gigi insisivus pada kasus borderline klas I yang dirawat dengan pencabutan 4 premolar kedua menjadi lebih retrusif daripada posisi gigi insisivus kasus borderline klas I yang dirawat tanpa pencabutan.Penelitian ini masih perlu dilanjutkan untuk melihat hubungan antara retraksi gigi insisivus dengan retraksi bibir dan pengaruh besarnya retraksi gigi anterior dan protraksi gigi molar anchorage terhadap perubahan profil wajah pada kasus borderline klas I.

\section{DAFTAR PUSTAKA}

1. Grabber LW, Vanarsdall RL, Vig KWL. Orthodontics current principles and techniques. Ed 5. Philadelphia: WB Saunders Co; 2012. H. 8-14, 561-80, 1023-32.

2. Al-Labban YR. A Cephalometric lips analysis and its relation to other cephalometric measurements in iraqi adult individuals. J Bagh Coll Dent. 2011; 23(3): 156-9.

3. Al Yami EA, Kuijpers-Jagtman AM, Van Hof MA. Stability of orthodontic treatment outcome: followup until 10 years postretention. Am J Orthod Dentofac Orthop.1999; 115: 300-4.

4. Perkins PA, Staley RN. Change in lip vermillion height during orthodontic treatment. Am J Orthod. 1993; 103: 147-54.

5. Linklater RA, Fox NA. The Long-term benefits of orthodontic treatment. British Dent J. 2002; 192(10): 583-7.

6. Saelens NA, De Smit AA. Therapeutic changes in extraction versus non-extraction orthodontic treatment. Am J Orthod Dentofac Orthop. 1998; 20: 225-36.

7. Lim HJ, Ko KT, Hwang HS. Esthetic impact of premolar extraction and nonextraction treatments on korean borderline patients. Am J Orthod Dentofac Orthop. 2008;133: 524-31.

8. Germec D, Taner U. Effects of extraction and nonextraction therapy with air-rotor stripping on facial esthetic in postadolescent borderline patients. Am J Orthod Dentofac Orthop. 2008;133: 539-49.

9. Bowman SJ, Johnston LE. The Esthetic impact of extraction and nonextraction treatments on caucasian patients. Angle Orthod. 2000; 70: 3-10.
10. Kocadereli I. Changes in soft tissue profile after orthodontic treatment with and without extractions. Am J Orthod Dentofac Orthop. 2002;122: 67-72.

11. Bascifti FA and Usumez S. Effects of extraction and nonextraction treatment on class I and class II subject. Angle Orthod. 2003; 73: 36-42.

12. Carey CW. Diagnosis and case analysis in orthodontic. Am J Orthod. 1951; 38: 149-61.

13. Xu T, Liu Y, Yang M, Huang W. Comparison of extraction versus nonextraction orthodontic treatment outcomes for borderline chinese patients. Am J Orthod Dentofac Orthop. 2006; 129: 672-7.

14. Bhalajhi SI. Orthodontics the art of science, Kuwait : Arya; 2000. H. 69-70, 176-7, 259-61.

15. Aksu M, Kocadereli I. Arch width changes in extraction and nonextraction treatment in class I patients. Angle Orthod. 2005; 75: 948-52.

16. Konstantonis D. The Impact of extraction vs nonextraction treatment on soft tissue changes in class i borderline malocclusions. Angle Orthod. 2012; 82: 209-17.

17. Drobocky OB, Smith RJ. Changes in facial profile during orthodontic treatment with extraction of four first premolars. Am J Orthod Dentofac Orthop. 1989; 95: 220-30.

18. Kusnoto $\mathrm{H}$. Penggunaan cepalometri radiografi dalam bidang ortodonti. Jakarta: Bagian Ortodonti FKG Universitas Trisakti; 1977. H. 3-15.

19. Al-Abdwani R, Moles DR, Noar JH. Change of incisor inclination effects on points $A$ and $B$. Angle Orthod. 2009; 79: 462-7.

20. Lew K. Profile change following orthodontic treatment of bimaxillary protrusion in adult with the begg appliance. Eur J Orthod. 1989; 11: 375-81.

21. Brock II RA, Taylor RW, Buschang PH, Behrents RG. Ethnic differences in upper lip response to incisor retraction. Am J Orthod Dentofac Orthop. 2005;127: 683-91.

22. Kasai K. Soft tissue adaptability to hard tissue in facial profiles. Am J Orthod Dentofac Orthop. 1998; 113: 674-84.

23. Profitt WR, Fields HW, Sarver DM. Contemporary orthodontics. Ed 4. St. Louis : The CV Mosby Co; 2007. H. 176-87, 276-84. 